\title{
The development and suppressive activity of soil microbial communities under compost amendment
}

\author{
M. Zaccardelli ${ }^{*}$, F. De Nicola ${ }^{2}$, D. Villecco ${ }^{1}$, and R. Scotti ${ }^{1}$ \\ ${ }^{1}$ Consiglio per la Ricerca e la Sperimentazione in Agricoltura, Centro di Ricerca per l'Orticoltura. Via dei Cavallegeri 25, 84098 \\ Pontecagnano (SA), Italy. 'Dipartimento di Scienze e Tecnologie, Università degli Studi del Sannio. Via Port'Arsa 11, 82100 \\ Benevento, Italy. Corresponding author: massimo.zaccardelli@entecra.it
}

\begin{abstract}
Soil is a highly complex system in which bacteria play a dominant role. Soil microorganism biodiversity is extremely important for sustaining the nutrient cycles of soil ecosystems. The diversity of soil bacterial and fungal communities can be influenced by agricultural management. The use of amendments, such as the incorporation of compost into the soil, strongly affects soil microbial communities directly or indirectly. The use of compost can be an important tool to control soil-borne pathogens. Certain groups of microorganisms (bacteria and fungi) present in compost produce metabolites, such as siderophores and antibiotics, with specific suppressive activity against soilborne pathogens: among these compost bacteria, species of Pseudomonas and Bacillus are very important. In this study, we investigated the effects of increasing doses of compost on the density of several cultivable soil microbial groups in an agricultural system of Southern Italy. The number of total bacteria, total fungi, siderophore-producing bacteria (principally Pseudomonas spp.) and spore-forming bacteria (principally Bacillus spp.) was evaluated over a period of five months. Moreover, we analyzed the ability of spore-forming bacteria isolated from soil and compost to inhibit, in vitro, five soil-borne phytopathogenic fungi (Rhizoctonia solani, Fusarium oxysporum, Sclerotinia minor, Fusarium solani, Pyrenochaeta lycopersici). The number of total bacteria and siderophore-producing bacteria was greater in the soil treated with compost than in soils treated with mineral fertilization or not manured, with an increase related to the dose of compost applied. Moreover, the compost used in this study produced a substantial increase in the number of spore-forming bacteria in the soil. Approximately $80 \%$ of these bacteria were able to inhibit the soil-borne phytopathogenic fungi Rhizoctonia solani, Fusarium oxysporum, Sclerotinia minor, Fusarium solani and Pyrenochaeta lycopersici. These results show that compost from the organic fraction of municipal solid wastes furnishes a high number of spore-forming bacteria exhibiting antibiotic activity against phytopathogenic fungi. The application of compost can change the composition of the soil microbial community, modifying the relationships among microorganisms, both competitive and/or antagonistic, producing a decrease in the activity of plant pathogens. These results were in agreement with the decrease in the symptoms of disease on tomato plants cultivated in the soils treated in this study.
\end{abstract}

Keywords: Bacteria, cultivable fungi, Bacillus spp., Pseudomonas spp., antibiosis, suppressiveness 


\section{Introduction}

Soil is a highly complex system in which trillions of organisms, e.g., algae, bacteria, fungi, protozoans, insects, mites and worms, are linked by complex ecological interactions. The soil microbial community exceeds, both in abundance and variety, the other communities that live in the soil; in fact, it is estimated that one gram of soil may harbor up to 10 billion microorganisms belonging to thousands of different species (Torsvik and Øvreås, 2002). However, it is important to remember that the quantification and assessment of soil microorganisms is influenced by the method of analysis (Crecchio et al., 2004), as only $1 \%$ of soil microorganisms are cultivable in the laboratory. Although molecular methods have been applied to study soil bacterial communities, they are not applied as widely to characterize soil fungi (van Elsas et al., 2000).

Currently, soil biodiversity is considered fundamental to sustaining ecosystem function. Soil biota play a key role in nutrient cycling, the decomposition of organic matter and the maintenance of soil fertility.

The dimension, composition and activities of soil bacterial and fungal communities can be strongly influenced by the quantity and type of nutrients, water content, aeration, temperature and $\mathrm{pH}$ as well as by agricultural management (Elliot, 1997). In fact, soil organisms respond to alteration due to tillage practices (Drury et al., 1991), the use of fertilizers and pesticides (Fauci and Dick, 1994) and, moreover, to the manipulation of organic residues (Franzluebber et al., 1995). The use of compost in the soil is of agronomic interest because it improves soil structure and quality (Albiach et al., 2000) and acts as a source of carbon and other nutrients, influencing soil microorganisms. Although it is known that compost amendment affects the soil microbial community, increasing the biomass (Albiach et al., 2000), the effect of compost amendment on the composition of the soil microbial community has seldom been investigated.
Moreover, in the past decade, the use of compost under field conditions has been found to be effective as a biocontrol agent (Keener et al., 2000) for the suppression of soil-borne plant pathogens (Cotxarrera et al., 2002), reducing the level of disease damage in economically important crops (Senthilraja et al., 2010). The biocontrol of soil-borne pathogens is related to specific suppression due to metabolites produced by antagonistic microorganisms (bacteria and fungi) that selectively increase the populations of the beneficial microorganisms (Liebman and Epstein, 1992).

Certain bacteria produce substances with a specific and significant role. For example, Pseudomonas spp. reduce root rot infection through several mechanisms, such as the induction of systemic resistance against phytopathogens in the host plant (Ramamoorthy et al., 2001). As reported in the literature, a bacterial suspension of $P$. fluorescens can inhibit the growth of Rizoctonia solani mycelia in rhizosphere soils and can also facilitate the colonization of plant roots by arbuscular mycorrhizal fungi (AMF), increasing plant growth and biomass (Neeraj and Singh, 2011). In general, it has been reported that several species of pseudomonads, such as $P$. fluorescens, $P$. putida, P. cepacia (Burkholderia cepacia) and $P$. aeruginosa, isolated from plant tissues or soil, are potential biocontrol agents for several phytopathogenic fungi (Mavrodi et al., 2012).

Among bacteria, Bacillus spp. also play a highly important role due to their ability to produce very active antibiotics, especially against fungi, to promote plant growth or to induce systemic resistance (Zaccardelli et al., 2003; Zaccardelli et al., 2004). Moreover, B. subtilis strains are known to inhibit several soil-borne fungi, such as $R$. solani, the causal agent of stem and stolon rot of peppermint (Kamalakannan et al., 2003).

It is highly important to understand how the addition of compost to soil can act on soil-borne pathogens, affecting both biotic and abiotic processes. 
In this context, the goal of this work was to highlight the effect of organic amendments on soil microbial densities and suppressiveness. For this purpose, the density of total bacteria, total fungi, siderophoreproducing bacteria and spore-forming bacteria in an agricultural soil amended with increasing doses of compost were evaluated in comparison with mineralfertilized or unfertilized soil. Additionally, the density and dynamics of spore-forming bacteria potentially able to control soil-borne phytopathogenic fungi were evaluated.

\section{Materials and Methods}

\subsection{Experimental field and design.}

Investigations were performed from March to July of 2005 at the experimental farm $\left(40^{\circ} 34^{\prime} \mathrm{N}, 14^{\circ} 58^{\prime}\right.$ $\mathrm{W}$, altitude $65 \mathrm{~m}$ a.s.1.) of CRA-ORT, Battipaglia, in the Sele River Plain (Salerno, Campania, Italy). The farm is characterized by a Clay Gleyc Luvisol (USDA, 1998). A complete randomized block design with three replications (plots) for five treatments was used. The five treatments were as follows: amendments with 15 (C15), 30 (C30) and 45 (C45) t ha ${ }^{-1}$ of dry compost (d.c.), mineral fertilization (150 kg ha-1 of N, $200 \mathrm{~kg}$ ha $^{-1}$ of $\mathrm{P}_{2} \mathrm{O}_{5}$ and $120 \mathrm{~kg} \mathrm{ha}^{-1}$ of $\mathrm{K}_{2} \mathrm{O}$ ) (MIN) and no amendment (CNT). Each plot, with a surface area of $68 \mathrm{~m}^{2}$, was cultivated with peeled tomato $\mathrm{cv}$. Galeon, with a density of 29,000 plants ha ${ }^{-1}$.

\subsection{Compost characteristics and manuring.}

The compost used in this study was obtained from the organic fraction of municipal solid wastes (MSW) mixed with trimmings in a $1: 1$ ratio $(\mathrm{V} / \mathrm{V})$ by a static system with forced aeration for one month and, thereafter, by natural aeration for approximately two months. MSW and trimmings were collected in various cities in the Vesuvius area (Campania Region, Italy). The composition of the compost was total organic carbon $29.4 \%$, total nitrogen $1.15 \%$ and organic nitrogen $1.04 \%$ of dry matter (d.m.); $\mathrm{C} / \mathrm{N}=28$ and $\mathrm{pH}=8.49$; the contents of heavy metals, inert and plastic materials were within legal limits of Italian law (L.D. 217/2006); Salmonella, cestodes, nematodes and trematodes were absent. Annually, from 2003 to 2005 (on April 9, 2003, May 10, 2004 and April 1, 2005), in the spring, compost was distributed on the soil surface and then incorporated at a depth of 15-20 cm one week before a horticultural crop was transplanted. For the MIN plots, phosphate and potassium mineral fertilizers were distributed before the transplanting of tomato plants, whereas nitrogen fertilizers were distributed in proportions of $1 / 3$ before transplanting and $2 / 3$ during crop growth.

\subsection{Soil sampling and processing.}

From each plot, soil samples were collected monthly from a depth of $20 \mathrm{~cm}$ from March to July 2005 for microbial analyses. Each soil sample, obtained by mixing together six sub-samples per plot, was sieved at $2 \mathrm{~mm}$ and stored at $4{ }^{\circ} \mathrm{C}$ for several days until analysis.

The water content was determined in all soil samples by the gravimetric method after oven-drying at $105^{\circ} \mathrm{C}$ to constant weight.

\subsection{Microbiological analyses.}

For each soil sample, four microbial groups were evaluated: total bacteria, siderophore-producing bacteria (principally Pseudomonas spp.), spore-forming bacteria (principally Bacillus spp.) and total fungi.

To obtain soil suspensions, a total of $5 \mathrm{~g}$ of sieved soil was shaken in a sterile flask ( $1 \mathrm{~h}$ at 120 r.p.m.) after the addition of $45 \mathrm{ml}$ of $0.1 \mathrm{M} \mathrm{pH} 7.6$ phosphate buffer. Microbial counting was performed by plating and incubating ten-fold dilutions of soil suspensions on semi-selective agar substrates. For total bacteria, soil extract agar with actidione added $\left(100 \mu \mathrm{g} \mathrm{ml}^{-1}\right)$ was used; for siderophore-forming bacteria, an agar nutritive substrate without iron (Scher and Baker, $1982)$ with actidione added $\left(100 \mu \mathrm{g} \mathrm{ml}^{-1}\right)$, was used; 
for spore-forming bacteria, nutrient agar was seeded with ten-fold dilutions of soil suspensions treated at $90{ }^{\circ} \mathrm{C}$ for $10 \mathrm{~min}$ to kill fungi and bacteria unable to produce thermal-resistant spores (Sadfi et al., 2001). To count total fungi, V8-agar with nalidixic acid $(150 \mu \mathrm{g}$ $\left.\mathrm{ml}^{-1}\right)$ and streptomycin $\left(150 \mu \mathrm{g} \mathrm{ml}^{-1}\right)$ added was used.

For each of the ten-fold dilutions, three replicates of 10 $\mu 1$ (for bacteria) or $50 \mu 1$ (for fungi) of the suspensions were seeded on the four agar substrates. Plates were incubated at $28{ }^{\circ} \mathrm{C}$ for $24-48 \mathrm{~h}$ (bacteria) or at $25^{\circ} \mathrm{C}$ (fungi) for 5-7 days (fungi), and the number of colonyforming units (CFU) was counted. The number of CFU was expressed per gram d.w. soil.

Counts of the four microbial groups in three subsamples of the compost used in this study were also performed.

\subsection{Selection of spore-forming bacteria with antibiotic activity}

From the ten-fold dilutions used to count sporeforming bacteria in the compost and in the soil samples collected in April, May and June 2005, single colonies were collected, grown on nutrientagar medium (NA) and then seeded along a board in PDA plates containing, at the center, a plug (diameter $6 \mathrm{~mm}$ ) of one of the phytopathogenic fungi used in this study, i.e., Rhizoctonia solani strain RT10, Fusarium oxysporum strain ATCC 16605, Sclerotinia minor ORT 1, Fusarium solani ISPAVE, Pyrenochaeta lycopersici strain 1392 . After incubation at $25^{\circ} \mathrm{C}$ for several days, the presence or absence of inhibition haloes in each bacterial isolate and colony of phytopathogenic fungi was recorded.

\subsection{Statistical analysis}

A one-way ANOVA followed by a Tukey's HSD (Honesty Significant Difference) post hoc test was performed to test the significance of differences in all investigated soil properties among different soil treatments at each sampling time. All statistical analyses were performed with SAS JMP 8 software.

\section{Results and Discussion}

At each sampling time and in all soil samples analyzed, the water content ranged from 12 to $17 \%$ d.w.

The microbial analyses indicated that the total number of bacteria (Figure $1 \mathrm{~A}$ ), expressed as the mean of the values of the five monthly samples from March to July 2005, was greater in the soils amended with compost than in the soils treated with mineral fertilizer or in the control plots. In particular, the total number of bacteria in the soil with the lowest dose of compost (C15) was approximately two-fold higher than the control (CNT), whereas the total number of bacteria in the soils treated with the highest doses of compost (C30 and C45) was significantly $(p<0.05)$ higher, as much as six-fold, than in the CNT (Figure 1 A).

Differences among treatments were particularly evident over time. In the samples collected in the last phase of the study, in June and July 2005, generally the total number of bacteria in $\mathrm{C} 15, \mathrm{C} 30$ and $\mathrm{C} 45$ was significantly $(p<0.05)$ higher than the total number in MIN and CNT (Table 1). The increase in total bacterial density in the amended plots was a result of enhanced microbial development due to the compost, which furnishes a sizeable pool of accessible nutrients to the microorganisms (Bailey and Lazarovits, 2003). Consistent with our results, an increase of up to ten times in the number of total bacteria has been observed in an agrarian soil manured with composted organic residues relative to soil treated with mineral fertilizers (Badr EL-Din et al., 2000).

The mean total number of fungi did not show a clear temporal trend (Table 1), in contrast to the total number of bacteria. The total number of fungi in the soils manured with compost was from $1.5(\mathrm{C} 45)$ to 2.5 times $(\mathrm{C} 15)$ higher than in the soils without organic amendment (MIN and CNT) (Figure 1 B). Consistent with these results, other authors have recorded a greater total number of fungi in plots manured with composted organic residues than in plots with mineral fertilizers only (Badr EL-Din et al., 2000), although the number 
of total cultivable fungi in this study (approximately $10^{3} \mathrm{CFU}$ ) both in the treated and the control plots was one order of magnitude less than the number recorded by Badr EL-Din et al., (2000).

The compost application did not have any lethal effect on the soil microflora, as the densities of cultivable bacteria and fungi remained constant or increased after amendment (Perez-Piqueres et al., 2006).

The number of bacteria (principally pseudomonads) that produce siderophores, molecules that complex iron atoms to solubilize and transport them into the cell (Scher and Baker, 1982), was not influenced significantly by the treatment with compost (Figure $1 \mathrm{C})$. The difference in the number of pseudomonads between the soils manured with compost and the unmanured soils was observed only in April and only in C45 soil (Table 1). Certain authors (Jensen et al., 2000) have demonstrated that the number of fluorescent pseudomonads isolated from soils of farms did not improve after amendment with animal organic residues; conversely, these authors isolated a substantial number of Pseudomonas spp. from untreated soils.
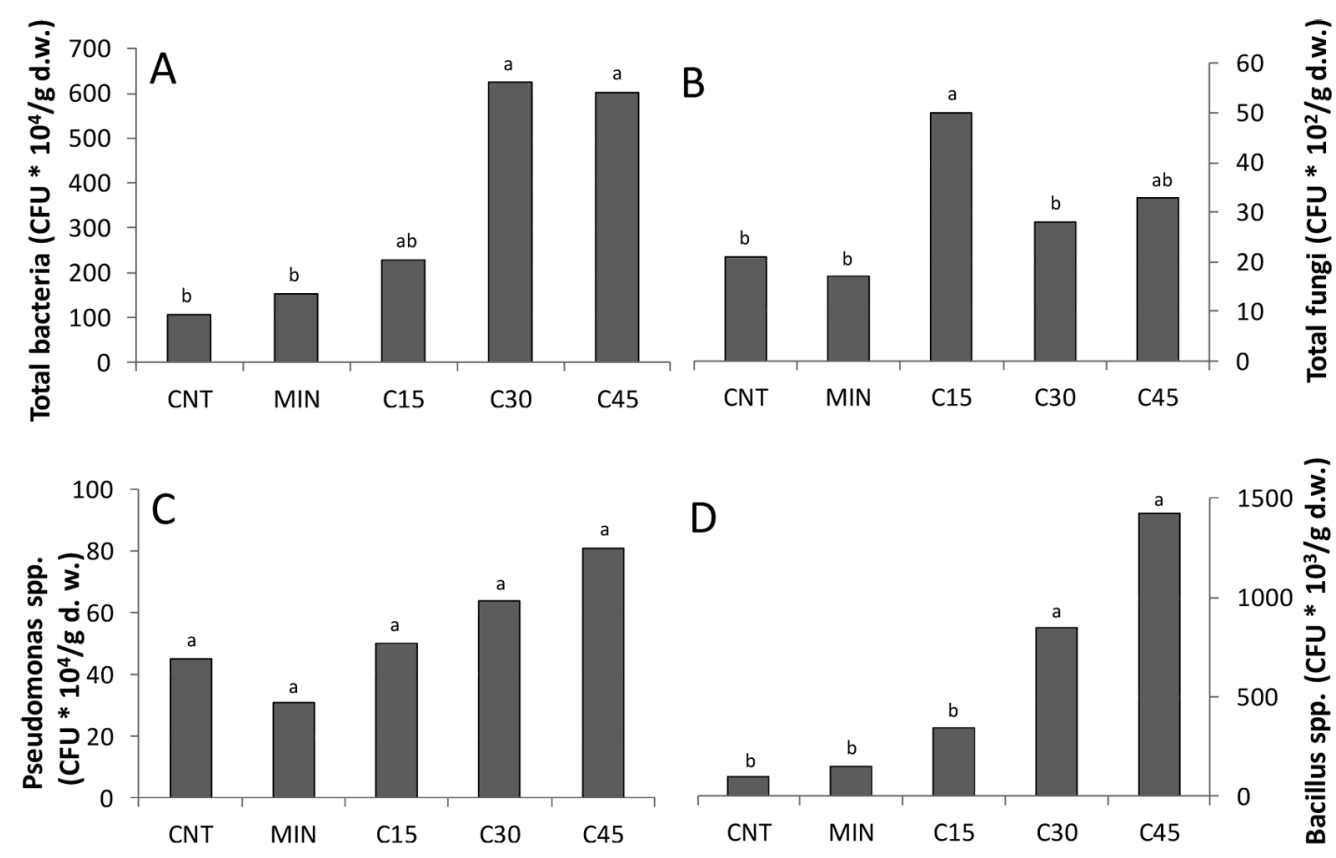

Figure 1. Mean density of total bacteria (A), total fungi (B), siderophore-producing bacteria (C) and spore-forming bacteria (D) in soils amended with 15 (C15), 30 (C30) and 45 (C45) t ha ${ }^{-1}$ of dry compost, mineral fertilization (MIN) and not amended (CNT). The results are reported as average of values of soil samples collected in five monthly samples from March to July 2005. (Note: data followed by different letters are significantly different according to the HSD test, $p<0.05$ ) 
Table 1. Density of various microorganisms examined (CFU g ${ }^{-1}$ d.w. soil) in soils amended with 15 (C15), 30 (C30) and 45 (C45) t ha ${ }^{-1}$ of dry compost, mineral fertilization (MIN) and not amended (CNT) over 5 monthly sampling times (from March to July).

\begin{tabular}{|c|c|c|c|c|}
\hline & $\begin{array}{c}\text { Total bacteria } \\
\left(\begin{array}{ll}\mathbf{x} & \left.10^{4}\right) \\
\end{array}\right.\end{array}$ & $\begin{array}{c}\text { Total fungi } \\
\left(\begin{array}{l}\text { x 10 } \\
\text { 10 }\end{array}\right)\end{array}$ & $\begin{array}{c}\text { Pseudomonas spp } \\
\left(\times 10^{4}\right)\end{array}$ & $\begin{array}{c}\text { Bacillus spp } \\
\quad\left(\mathrm{x} 10^{3}\right)\end{array}$ \\
\hline \multicolumn{5}{|l|}{ March } \\
\hline CNT & 61 a & $41 \mathrm{ab}$ & $34 \mathrm{a}$ & 170 a \\
\hline MIN & 61 a & $9 \mathrm{~b}$ & 55 a & 142 a \\
\hline $\mathrm{C} 15$ & $170 \mathrm{a}$ & 68 a & 38 a & 176 a \\
\hline C30 & $117 \mathrm{a}$ & $9 \mathrm{~b}$ & 78 a & 268 a \\
\hline $\mathrm{C} 45$ & 48 a & $17 \mathrm{ab}$ & $46 \mathrm{a}$ & 284 a \\
\hline \multicolumn{5}{|l|}{ April } \\
\hline CNT & 263 a & 9 a & $15 \mathrm{~b}$ & $74 \mathrm{~b}$ \\
\hline MIN & 273 a & $17 \mathrm{a}$ & $20 \mathrm{~b}$ & $246 \mathrm{~b}$ \\
\hline $\mathrm{C} 15$ & $407 \mathrm{a}$ & $34 \mathrm{a}$ & $134 \mathrm{ab}$ & $590 \mathrm{ab}$ \\
\hline C30 & 1924 a & $41 \mathrm{a}$ & $131 \mathrm{ab}$ & $1124 \mathrm{ab}$ \\
\hline $\mathrm{C} 45$ & 1625 a & 26 a & 204 a & 3814 a \\
\hline \multicolumn{5}{|l|}{ May } \\
\hline CNT & $20 \mathrm{a}$ & $12 \mathrm{a}$ & $11 \mathrm{a}$ & $101 \mathrm{~b}$ \\
\hline MIN & 96 a & $20 \mathrm{a}$ & 25 a & $127 \mathrm{~b}$ \\
\hline C15 & 144 a & $55 \mathrm{a}$ & 25 a & $542 \mathrm{ab}$ \\
\hline C30 & 532 a & $41 \mathrm{a}$ & $30 \mathrm{a}$ & 1580 a \\
\hline $\mathrm{C} 45$ & 499 a & 62 a & 79 a & 1035 a \\
\hline \multicolumn{5}{|l|}{ June } \\
\hline $\mathrm{CNT}$ & $88 \mathrm{c}$ & $16 \mathrm{ab}$ & 114 a & $45 \mathrm{c}$ \\
\hline MIN & $205 \mathrm{~b}$ & $10 \mathrm{ab}$ & $25 \mathrm{a}$ & $40 \mathrm{c}$ \\
\hline C15 & $111 \mathrm{c}$ & 28 a & $10 \mathrm{a}$ & $201 \mathrm{~b}$ \\
\hline C30 & 297 a & $6 \mathrm{~b}$ & 22 a & $486 \mathrm{ab}$ \\
\hline $\mathrm{C} 45$ & $226 a b$ & $25 \mathrm{ab}$ & 30 a & 903 а \\
\hline \multicolumn{5}{|l|}{ July } \\
\hline $\mathrm{CNT}$ & $88 \mathrm{~d}$ & $26 \mathrm{a}$ & 50 a & $88 \mathrm{~b}$ \\
\hline MIN & $121 \mathrm{~cd}$ & 28 a & 30 a & $195 \mathrm{~b}$ \\
\hline C15 & $311 \mathrm{~b}$ & $68 \mathrm{a}$ & 43 a & $210 \mathrm{~b}$ \\
\hline C30 & $258 \mathrm{~b}$ & $41 \mathrm{a}$ & 57 a & 768 а \\
\hline C45 & 609 а & 36 a & $47 \mathrm{a}$ & 1082 a \\
\hline
\end{tabular}

(Note: for each sampling time, data followed by different letters are significantly different according to the HSD test $(p<0.05)$.) 
The number of spore-forming bacteria (principally Bacillus spp.), expressed as the mean of the values of the five monthly samples from March to July 2005, was significantly $(p<0.05)$ greater in the soils with compost (C15, C30, C45) than in the soils without compost (MIN, CNT), with an increase that was related to the dose of compost applied (Figure $1 \mathrm{D}$ ). In particular, the number of these thermally resistant bacteria in the $\mathrm{C} 30$ and $\mathrm{C} 45$ plots was significantly higher than that in CNT in April (Table 1). Consistent with these results, Jensen et al. (2000) showed that the number of Bacillus cereus groups isolated from agricultural soils was higher in plots amended with manure than in untreated plots. Additionally, the characterization of a soil amended with compost from an experimental field in Lisse (The Netherlands) highlighted a microbial community containing several Bacillus and Pseudomonas-like sequences (Kowalchuk et al., 2003).

Microbiological analyses performed on compost showed a higher variability for all the four microbial groups analyzed, as indicated by the values of the standard error (Table 2).

Table 2. Density ( \pm s.e.) of microorganisms (CFU g-1 d.w. compost) in the compost from organic fraction of municipal solid wastes (MSW) used for this study in 2005.

\begin{tabular}{llll}
\hline Total & Total & Pseudomonas & Bacillus \\
Bacteria & Fungi & spp. & spp. \\
$\left.\mathbf{( x 1 0}^{\mathbf{}}\right)$ & $\left.\mathbf{( x 1 0}^{\mathbf{}}\right)$ & $\left.\mathbf{( x 1 0}^{4}\right)$ & $\left.\mathbf{( x 1 0}^{3}\right)$ \\
\hline $367 \pm 62$ & $693 \pm 267$ & $905 \pm 530$ & $3589 \pm 1097$ \\
\hline
\end{tabular}

A comparison of the number of microorganisms measured in the compost with the number measured in the soils treated with compost clearly showed that the number of bacteria and fungi in the compost was substantially greater: in fact, the total number of bacteria in the compost was 1000 times greater than in the amended soils, the number of fungi and Pseudomonas spp. was 20 times greater and the number of Bacillus spp. was three times greater (Tables 1 and 2). These results indicate that the incorporation of compost in the soil results in a dilution effect. In recent years, several studies have investigated the use of organic amendments in agricultural soils, and certain authors have reported that both single and repeated applications of different doses of organic amendment (in particular, sludge) have improved the soil microbial biomass and the potential mineralization of nitrogen. Nevertheless, the highest application $\left(100 \mathrm{t} \mathrm{ha}^{-1}\right)$ reduced the functional diversity of the microbial community (Banerjee et al., 1997).

Table 3 and Figure 2 show the in vitro suppressiveness found for the spore-forming bacteria isolated from compost obtained from municipal solid waste against the "soil-borne" phytopathogenic fungi Rhizoctonia solani, Sclerotinia minor, Fusarium solani, Fusarium oxysporum and Pyrenochaeta lycopersici. The results showed a high density of spore-forming bacteria with antibiotic activity against the fungi tested. The inhibition was due to the production of substances with fungitoxic activity. 
Table 3. Population density (CFU g ${ }^{-1} \mathrm{~d}$. w. compost) of spore-forming bacteria and antibiotic activity against the "soil-borne" phytopathogenic fungi Rhizoctonia solani, Sclerotinia minor, Fusarium solani, Fusarium oxysporum and Pyrenochaeta lycopersici. Spore-forming bacteria isolated from compost of organic fraction from municipal solid wastes (MSW) used in this study.

\begin{tabular}{|c|c|c|c|c|c|}
\hline $\begin{array}{l}\text { Population density } \\
\qquad \times 10^{5}\end{array}$ & $\begin{array}{c}\text { Rhizoctonia } \\
\text { solani }\end{array}$ & $\begin{array}{l}\text { Sclerotinia } \\
\text { minor }\end{array}$ & $\begin{array}{c}\text { Fusarium } \\
\text { solani }\end{array}$ & $\begin{array}{l}\text { Fusarium } \\
\text { oxysporum }\end{array}$ & $\begin{array}{c}\text { Pyrenochaeta } \\
\text { lycopersici }\end{array}$ \\
\hline 5.4 & + & - & + & - & + \\
\hline 5.4 & - & - & + & - & - \\
\hline 3.6 & - & + & + & + & - \\
\hline 3.6 & - & + & - & - & - \\
\hline 3.6 & - & - & - & - & + \\
\hline 1.8 & - & + & + & - & + \\
\hline 1.8 & - & - & + & + & - \\
\hline 1.8 & + & + & - & - & - \\
\hline 1.8 & + & - & - & - & + \\
\hline
\end{tabular}

(Note: - = absence of antibiosis; $+=$ presence of antibiosis.)

Of a mean density of spore-forming bacteria of approximately $3.6 \times 10^{6} \mathrm{CFU} \mathrm{g}^{-1}$ d.w. of compost, approximately $2.9 \times 10^{6} \mathrm{CFU} \mathrm{g}^{-1}$ showed antibiotic activity. Therefore, approximately $80 \%$ of the sporeforming bacteria in the compost evaluated were potentially antagonistic. These data indicate that this compost is able to suppress plant diseases caused by soil-borne fungi. In fact, $43.75 \%$ of the spore-forming bacteria were able to inhibit the growth of only one of the five phytopathogenic fungal species tested, $18.75 \%$ inhibited two fungal species, $37.50 \%$ inhibited three fungal species and no spore-forming bacteria inhibited all four fungal species. In particular, 31.25\% inhibited the growth of Rhizoctonia solani, $37.50 \%$ inhibited the growth of Sclerotinia minor, $62.50 \%$ inhibited the the growth of Fusarium solani, $18.75 \%$ inhibited the growth of Fusarium oxysporum and $43.75 \%$ inhibited the growth of Pyrenochaeta lycopersici.

Table 4 shows the results for the density and the suppressiveness of the spore-forming bacteria isolated from all soil samples collected in April, May and June.

The number of colonies of spore-forming bacteria isolated and tested in vitro for antibiotic activity against the five phytopathogenic fungi was 99 in April, 86 in May and 97 in June. Overall, the percentage of sporeforming bacteria showing antibiotic activity against the phytopathogenic Rhizoctonia solani, Sclerotinia minor, Fusarium solani and Fusarium oxysporum was 
$35 \%$ in April, $15 \%$ in May and 2\% in June; in contrast, the percentage showing antibiotic activity against Pyrenochaeta lycopersici was $78 \%$ in April, $41 \%$ in May and $73 \%$ in June. In April, approximately one month after the final incorporation of compost into the soil, $83 \%$ of the spore-forming bacteria with antibiotic activity were isolated from the soils amended with compost, whereas only $5 \%$ and $12 \%$ were isolated from the chemically fertilized plots and the control plots, respectively. Moreover, the density of sporeforming bacteria with antibiotic activity ranged from $3.6 \times 10^{5} \mathrm{CFU} \mathrm{g}^{-1}$ d.w. of soil to $57.6 \times 10^{5} \mathrm{CFU} \mathrm{g}^{-1} \mathrm{~d}$.w. of soil in plots amended with compost and from $0.18 \mathrm{x}$ $10^{5} \mathrm{CFU} \mathrm{g}^{-1} \mathrm{~d}$.w. of soil to $1.8 \times 10^{5} \mathrm{CFU} \mathrm{g}^{-1} \mathrm{~d}$.w. of soil in the plots without compost addition. These data show that compost from the organic fraction of municipal solid wastes contains a high number of sporeforming bacteria showing antibiotic activity against phytopathogenic fungi. The compost amendment can change the composition of the soil microbial community, modifying the relationships among microorganisms, both competitive and/or antagonistic, producing a decrease in the activity of plant pathogens (Steinberg et al., 2004). The suppression of disease due to $R$. solani in soil amended with compost has also been reported by Perez-Piqueres et al. (2006). The reduction in the growth of $R$. solani in the soils amended with compost can be correlated with the higher density of pseudomonads in these plots.

The results of the antibiosis tests performed on the sporeforming bacteria isolated in April indicate that 34.1\% of the bacteria inhibited all five phytopathogenic fungi, 9.7\% inhibited four fungal species, $17.1 \%$ inhibited three fungal species, $17.1 \%$ inhibited two fungal species and $22 \%$ inhibited one fungal species. In detail, $68 \%$ of the spore-forming bacteria inhibited the growth of Rhizoctonia solani, 54\% that of Sclerotinia minor, $66 \%$ that of Fusarium solani, $44 \%$ that of Fusarium oxysporum and $88 \%$ that of Pyrenochaeta lycopersici.

The quantity of spore-forming bacteria with antibiotic activity was very low in the soil samples collected in May and June; in June, no bacterial strain able to inhibit the growth of Rhizoctonia solani and Sclerotinia minor was isolated. Conversely, the frequencies of spore-forming bacteria with antibiotic activity against Pyrenochaeta lycopersici were higher in May and June and reached $100 \%$ at the last sampling time.

The last-cited results are in agreement with the decrease observed in the symptoms of corky root rot on tomato plants cultivated in the soils amended with compost in this study. In fact, a disease severity index of 1.1 and 1.8 was recorded in soils amended with 15 and $45 \mathrm{t} \mathrm{ha}^{-1}$ d.w. of compost, respectively, whereas the disease severity index was 2.8 in soils amended with mineral fertilizers (Zaccardelli et al., 2006; Zaccardelli et al., 2010).

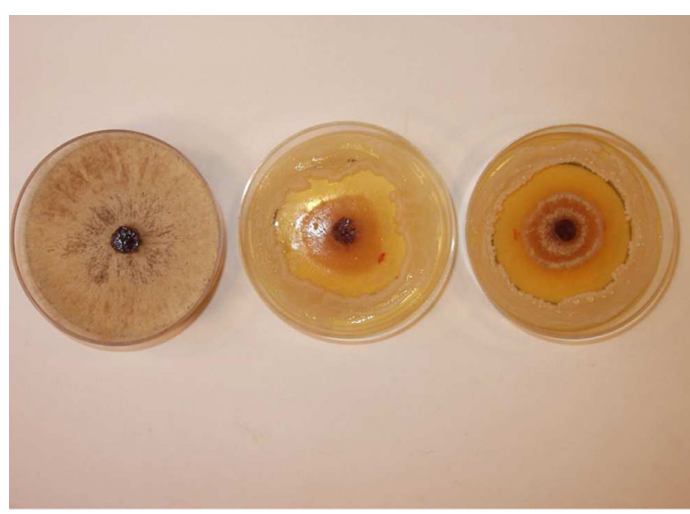

Figure 2. In vitro antibiotic activity against phytopathogenic fungus Rhizoctonia solani due to spore-forming bacteria isolated from the compost used in this study. The plate on the left contains the fungus only (control), whereas the central plate and the plate on the right contain the fungus at the center and the bacteria along the margin of the plate. 
Table 4. Population density (CFU g-1 d.w.) of spore-forming bacteria and antibiotic activity against soil-borne phytopathogenic fungi Rhizoctonia solani, Sclerotinia minor, Fusarium solani, Fusarium oxysporum and Pyrenochaeta lycopersici. Spore-forming bacteria isolated from soils amended with 15 (C15), 30 (C30) and 45 (C45) tha ${ }^{-1}$ of dry compost, mineral fertilization (MIN) and not amended (CNT), collected in April, May and June 2005 during tomato

\begin{tabular}{|c|c|c|c|c|c|c|c|}
\hline $\begin{array}{c}\text { Sampling } \\
\text { time }\end{array}$ & $\begin{array}{c}\text { Soil } \\
\text { treatment }\end{array}$ & $\begin{array}{c}\text { Population } \\
\text { density } \times 10^{5}\end{array}$ & $\begin{array}{c}\text { Rhizoctonia } \\
\text { solani }\end{array}$ & $\begin{array}{l}\text { Sclerotinia } \\
\text { minor }\end{array}$ & $\begin{array}{l}\text { Fusarium } \\
\text { solani }\end{array}$ & $\begin{array}{c}\text { Fusarium } \\
\text { oxysporum }\end{array}$ & $\begin{array}{c}\text { Pyrenochaeta } \\
\text { lycopersici }\end{array}$ \\
\hline April & C15 & 21.6 & - & - & - & - & + \\
\hline$"$ & $"$ & 3.6 & + & + & + & + & + \\
\hline$"$ & $"$ & 3.6 & + & + & + & - & + \\
\hline$"$ & $"$ & 1.8 & - & + & - & - & + \\
\hline$"$ & $"$ & 1.8 & - & - & + & + & - \\
\hline$"$ & $"$ & 1.8 & - & $+1-$ & - & - & + \\
\hline$"$ & C30 & 1.8 & + & - & - & - & + \\
\hline$"$ & " & 1.8 & + & + & - & - & + \\
\hline$"$ & $"$ & 1.8 & - & - & - & - & + \\
\hline$"$ & $"$ & 37.8 & + & + & + & + & + \\
\hline$"$ & $"$ & 18 & + & - & + & + & + \\
\hline$"$ & $"$ & 18 & - & $+1-$ & - & - & + \\
\hline$"$ & $"$ & 1.8 & + & + & - & - & - \\
\hline$"$ & $"$ & 1.8 & - & + & - & - & $+1-$ \\
\hline$"$ & $"$ & 1.8 & - & + & - & + & $+1-$ \\
\hline$"$ & C45 & 1.8 & + & - & + & - & $+1-$ \\
\hline$"$ & $"$ & 73.8 & + & - & + & - & + \\
\hline$"$ & $"$ & 57.6 & + & + & + & + & + \\
\hline$"$ & $"$ & 18 & + & - & + & - & + \\
\hline$"$ & $"$ & 1.8 & - & - & + & - & + \\
\hline$"$ & MIN & 1.8 & + & + & + & + & - \\
\hline$"$ & " & 1.8 & + & + & + & + & + \\
\hline$"$ & CNT & 0.36 & - & - & - & - & + \\
\hline$"$ & $"$ & 0.54 & + & + & + & + & + \\
\hline May & C15 & 1.8 & - & - & - & - & + \\
\hline$"$ & $\mathrm{C} 30$ & 18 & + & - & - & - & + \\
\hline$"$ & C45 & 22 & + & - & - & - & + \\
\hline$"$ & MIN & 2.16 & - & - & - & - & + \\
\hline$"$ & $"$ & 0.18 & + & - & - & - & + \\
\hline$"$ & $"$ & 0.18 & + & - & + & $+1-$ & - \\
\hline$"$ & $"$ & 0.18 & + & + & + & + & + \\
\hline$"$ & $\mathrm{CNT}$ & 0.18 & + & + & - & + & + \\
\hline June & C15 & 5.4 & - & - & - & - & + \\
\hline " & $\mathrm{C} 30$ & 3.6 & - & - & - & - & + \\
\hline$"$ & $"$ & 1.8 & - & - & - & + & + \\
\hline$"$ & $"$ & 1.8 & - & - & + & - & + \\
\hline$"$ & C45 & 1.8 & - & - & - & - & + \\
\hline$"$ & " & 1.8 & - & - & + & + & + \\
\hline$"$ & $"$ & 1.8 & - & - & - & + & + \\
\hline$"$ & MIN & 0.54 & - & - & - & - & + \\
\hline$"$ & CNT & 1.8 & - & - & - & - & + \\
\hline
\end{tabular}

(Note: $-=$ no antibiosis; $+=$ antibiosis; $+/-=$ partial antibiosis.) 


\section{Conclusions}

The results of this study showed a clear positive effect on bacterial density of amendment with compost obtained from municipal solid waste and, in particular, on the number of spore-forming bacteria, with an increase directly correlated with the dose of compost. In contrast, mineral fertilization did not affect the density and the composition of the microbial communities studied. The improvement of this group of bacteria in an agricultural soil is highly important for the control of soil-borne fungi. In fact, the majority of the sporeforming bacteria isolated from the compost used in this study and selected during the composting process showed in vitro antibiotic activity against soil-borne phytopathogenic fungi such as Fusarium oxysporum, Fusarium solani and Rhizoctonia solani. Moreover, a greater decrease in damage by Pyrenochaeta lycopersici to tomato roots has been found in the same soil amended with compost (Zaccardelli et al., 2006; Zaccardelli et al., 2010). These results confirm that compost obtained from the organic fraction of municipal solid wastes produced an increase of suppressiveness against phytopathogenic fungi due to a change in the composition of the soil microbial community and a modification of the relationships among microorganisms, both competitive and/or antagonistic, producing a decrease in the activity of plant pathogens.

\section{Acknowledgments}

This research was performed with financial support from the Campania Region - SeS.I.R.C.A.

\section{References}

Albiach, R., Canet, R., Pomares, F., Ingelmo, F. 2000. Microbial biomass content and enzymatic activities after application of organic amendments to a horticultural soil. Bioresour. Technol. 75, 43-48
Badr EL-Din, S.M.S., Attia, M., Abo-Sedera, S.A. 2000. Field assessment of composts produced by highly effective cellulolytic microorganisms. Biol. Fertil. Soils. 32, 35-40.

Bailey, K.L., Lazarovits, G. 2003. Suppressing soilborne diseases with residue management and organic amendments. Soil Tillage Res. 72, 169-180.

Banerjee, M.R., Burton, D.L., Depoe, S. 1997. Impact of sewage sludge application on soil biological characteristics. Agric. Ecosyst. Envir. 66, 241-249.

Cotxarrera, L., Trillas-Gay, M.I., Steinberg, C., Alabouvette, C. 2002. Use of sewage sludge compost and Trichoderma asperellum isolates to suppress Fusarium wilt of tomato. Soil Biol. Biochem. 34, 467-476.

Crecchio, C., Curci, M., Pizzigallo, M.D.R., Ricciuti, P., Ruggiero, P. 2004. Effects of municipal solid waste compost amendments on soil enzyme activities and bacterial genetic diversità. Soil Biol. Biochem. 36, 1595-1605.

Drury, C.F., Stone, J.A., Findlay, W.I. 1991. Microbial biomass and soil structure associated with corn, grass and legumes. Soil Sci. Soc. of Amer. J. 55, 805-811.

Elliott, E.T. 1997. Rationale for developing bioindicators of soil health. In: Pankhurst C.E., Doube B.M., Gupta V.V.S.R. (eds). Biological Indicators of Soil Health. CAB International, New York, pp. 49-78.

Fauci, M.F., Dick, R.P. 1994. Soil microbial dynamics: Short and long-term effects of organic and inorganic nitrogen. Soil Sci. Soc. of Amer. J. 58, 801-808.

Franzluebber, A.J., Hons, F.M., Zuberer, D.A. 1995. Soil organic carbon, microbial biomass and mineralisable carbon and nitrogen in sorghum. Soil Sci. Soc. of Amer. J. 59, 460-466. 
Jensen, B.L., Baloda, S., Boye, M., Aerestrup, F.M. 2000. Antimicrobial resistance among Pseudomonas spp. and the Bacillus cereus group isolated from Danish agricultural soil. Envir. Int. 26, 581-587.

Kamalakannan, A., Mohan, L., Kavitha, K., Harish, S., Radjacommare, R., Nakkeeran, S., Parthiban, V. K., Angayarkanni, T. 2003. Enhancing resistance to stem stolon rot of pepper mint (Mentha piperita L.) using biocontrol agents. Acta Phytopathol. Hun. 38, 293-305.

Keener, H.M., Dick, W.A., Hoitink, H.A.J. 2000. Composting and beneficial utilization of composted by-product materials. In: Bartels J.M., Dick W.A. (eds). Land Application of Municipal, Agricultural, Industrial, and Municipal Byproducts. Soil Science Society of America, Book Series 6, 315-341.

Kowalchuk, G.A., Os, G.J., Aartrijk, J., Veen, J.A. 2003. Microbial community responses to disease management soil treatments used in flower bulb cultivation. Biol. Fertil. Soils. 37, 55-63.

Legislative Decree, 2006. Decreto Legislativo n. 217, 29 April 2006: Revisione della disciplina in materia di fertilizzanti. Gazzetta Ufficiale della Repubblica Italiana 141.

Liebman, J.A., Epstein, L. 1992. Activity of fungistasis compounds from soil Phytopathology. 82, 147-153.

Mavrodi, O. V., Walter, N., Elateek, S., Taylor, C. G., Okubara, P. A. 2012. Suppression of Rhizoctonia Pythium root rot of wheat by new strains of Pseudomonas. Bio. Control. 62, 93-102.

Neeraj, Singh, K. 2011. Organic amendments to soil inoculated arbuscular mycorrhizal fungi and Pseudomonas fluorescens treatments reduce the development of root-rot disease and enhance the yield of Phaseolus vulgaris L. Eur. J. Soil Biol. 47, 288-295.
Pérez-Piqueres, A., Edel-Hermann, V., Alabouvette, C., Steinberg, C. 2006. Response of soil microbial communities to compost amendments. Soil Biol. Biochem. 38, 460-470.

Ramamoorthy, V., Viswanathan, R., Raguchander, T., Prakasam, V., Samiyappan, R. 2001. Induction of systemic resistance by plant growth promoting rhizobacteria in crop plants against pests and diseases. Crop Prot. 20, 1-11.

Sadfin, N., Cherif, M., Fliss, I., Boudabbous, A., Antoun, H. 2001. Evaluation of bacterial isolates from salty soils and Bacillus thuringiensis strains for the biocontrol of Fusarium dry rot of potato tubers. J. Plant Pathol. 83, 101-118.

Scher, F. M., Baker, R. 1982. Effect of Pseudomonas putida and a sinthetic iron chelator on induction of soil suppressiveness to Fusarium Wilt pathogens. Phytopathology. 72, 1567-1573.

Senthilraja, G., Anand, T., Durairaj, C., Kennedy, J. S., Suresh, S., Raguchander, T., Samiyappana, R. 2010. A new microbial consortia containing entomopathogenic fungus, Beauveria bassiana and plant growth promoting rhizobacteria Pseudomonas fluorescens for simultaneous management of leaf miners and collar rot disease in groundnut. Biocontrol Sci. Technol. 20 (5), 449-464.

Steinberg, C., Edel-Hermann, V., Guillemaut, C., Pérez-Piqueres, A., Singh, P., Alabouvette, C. 2004. Impact of organic amendments on soil suppressiveness to diseases. In: Sikora R.A., Gowen S., Hauschild R., Kiewnick S. (eds). Multitrophic Interactions in Soil and Integrated Control IOBC wprs Bulletin, vol. 27, pp. 259266.

Torsvik, V., Øvreås, L. 2002. Microbial diversity and function in soil: From genes to ecosystems. Curr. Opin. Microbiol. 5, 240-245. 
USDA, 1998. United States Department of Agriculture Natural Resources Conservation Service, Soil Survey Staff. Keys to Soil Taxonomy. Washington.

van Elsas, J.D., Duarte, G.F., Keijzer-Wolters, A., Smit, E. 2000. Analysis of the dynamics of fungal communities in soil via fungal-specific PCR of soil DNA followed by denaturing gradient gel electrophoresis. J. Microbiol. Methods. 43, 133-151.

Zaccardelli, M., Lahoz, E., Del Galdo, A., Carella, A., Porrone, F. 2003. Antagonism of Bacillus spp. against Rhizoctonia solani and Fusarium sambucinum on potato. J. of Plant Pathol. 85, (4, Special issue), 299.

Zaccardelli, M.,. Carella, A, Caiazzo, R., Torre, R., Tarantino, P., Lahoz, E. 2004. Evaluation of two Bacillus spp. isolates inoculated on potato for antagonism against Rhizoctonia solani, plant growth promotion and improvement of $\beta$-1,4-glycosidases, $\beta$ D-N-N'-diacetylchitobiosidase and peroxidases activities. J. Plant Pathol. 86, (4, Special issue),337.

Zaccardelli M., Perrone D., Del Galdo A., Giordano I., Villari G., Bianco M. 2006. Multidisciplinary approach to validate compost use in vegetable crop systems in Campania Region (Italy): effect of compost fertilization on processing tomato in field cultivation. Acta Hort. 700, 285-288.

Zaccardelli, M., Pane, C., Perrone, D., Pucci, N., Infantino, A. 2010. Control of corky root of tomato with compost and role of spore-forming bacteria to inhibit Phyrenochaeta lycopersici. III International Symposium on Tomato Diseases; July 25-30, 2010, Ischia (NA) (Italy). 